\title{
Cell Therapy for Age-Related Disorders: Myocardial Infarction and Stroke - A Mini-Review
}

\author{
Brent A. Williams ${ }^{a, b} \quad$ Armand Keating $^{a, b}$ \\ ${ }^{a}$ Cell Therapy Program, Princess Margaret Hospital/Ontario Cancer Institute, and ${ }^{b}$ Institute of Medical Science, \\ Faculty of Medicine, University of Toronto, Toronto, Ont., Canada
}

\section{Key Words}

Cell therapy $\cdot$ Stem cell $\cdot$ Myocardial infarction $\cdot$ Stroke

\begin{abstract}
Background: The leading causes of death and disability in the elderly are from cardiovascular and cerebrovascular diseases. The biological role of stem cells in the hematopoietic system has been well characterized and has led to the development of hematopoietic stem and progenitor cell (HSPC) transplantation for the treatment of numerous malignant and nonmalignant diseases. More recently, stem cells have been found in many other tissues of the body including the heart and brain. As the field of stem cell biology has progressed, cell therapies for the treatment of myocardial infarction and stroke have been tested in early stage clinical trials using a variety of cellular agents. Objective: To review the clinical evidence supporting the role of cell therapies for myocardial infarction and stroke. Methods: A systematic review of the literature was conducted to identify clinical trials using cell therapies for myocardial infarction and stroke. $\boldsymbol{R} \boldsymbol{e}$ sults: Clinical trials of granulocyte colony-stimulating factor to mobilize HSPC after percutaneous coronary intervention for acute myocardial infarction have not shown clinical benefit. Direct delivery of HSPC to coronary arteries supplying the infarcted region using percutaneous coronary intervention does improve hemodynamic endpoints such as left ven-
\end{abstract}

tricular ejection fraction in many studies. One randomized trial demonstrated improvement in clinically meaningful endpoints such as death, recurrence of myocardial infarction and re-hospitalization for heart failure. Several small trials of cell therapy for stroke have been reported, including cytokine-mobilized HSPC, mesenchymal stromal cells and cell lines transplanted stereotactically into the region affected by stroke. Conclusions: In some prospective randomized trials, cell therapy for myocardial infarction leads to improvement in hemodynamic parameters. Cell therapy for stroke is a relatively new area of translational and clinical research with preliminary studies showing safety and some measurable benefit in small numbers of subjects.

Copyright $\odot 2008$ S. Karger AG, Basel

\section{Introduction}

Aging is a complex process that can be defined as a time-dependent series of cumulative, progressive, intrinsic and deleterious functional and structural changes in the body [1]. The diseases of aging are numerous and include cancer, cardiovascular, cerebrovascular and neurodegenerative diseases. Much of the of morbidity and mortality in the elderly is attributable to acute ischemic events leading to myocardial infarction or stroke, ultimately leading to cellular death of myocytes or neurons, respec-

\section{KARGER}

Fax +4161306 1234 E-Mail karger@karger.ch www.karger.com
(ㄷ) 2008 S. Karger AG, Basel

0304-324X/08/0545-0300\$24.50/0

Accessible online at:

www.karger.com/ger
Brent Williams, MD

Princess Margaret Hospital, 610 University Avenue, Suite 5-303

Toronto, Ont. M5G 2M9 (Canada)

Tel. +1 416946 4595, ext. 2, Fax +1 4169464530

E-Mail brentw@uhnres.utoronto.ca or brentwilliams.brent@gmail.com 
tively. A Report From the American Heart Association Statistics Committee on stroke and heart disease published in 2007 reported that 79.4 million Americans over the age of $20(37.1 \%)$ had some form of cardiovascular disease and in 2004 just under 900,000 deaths were attributable to heart disease with the total cost estimated at 431.8 billion dollars per annum [2]. On a global scale it has been estimated that 17 million people die each year from stroke and heart disease and that low- and middleincome countries account for about $80 \%$ of these deaths with a predicted tripling of ischemic heart disease and stroke mortality in Latin America, the Middle East and sub-Saharan Africa over the next two decades [3]. The WHO estimates that by 2030 the total deaths attributable to cardiovascular disease will increase to 23 million per year [4].

One solution to the problem of diseases of aging is through preventative medicine which has the goal to prevent the progression of age-related disease by diet, exercise and pharmacotherapy. While effective, this approach typically delays age-related diseases rather than preventing them. Inevitably, aging leads to degeneration in one or more organ systems, ultimately causing disability and death. The most potent intervention for treating endstage organ failure currently is organ transplantation. In the case of cardiac transplantation, this is the final therapeutic maneuver to treat end-stage heart failure from a variety of causes, including myocardial infarction. However, this approach has a high morbidity and mortality rate from the surgical procedure, immune rejection and immunosuppressive medications. Further, because of a limited supply of organ donors this approach can only be used to treat a select few. Also, whole organ transplantation is a seemingly excessive approach if only a small critical part of an organ is impaired. Cell therapies could potentially be more effective treatments for whole organ dysfunction because they could reconstitute the deficient tissue within an organ rather than replacing it in toto.

In this review, basic stem cell biology will be discussed briefly to provide a framework to understand current and future therapeutic clinical trials using cell therapies to treat myocardial infarction and stroke.

\section{Stem Cell Biology: From Hematopoiesis to Other Systems}

Stem cell biology has advanced rapidly since 1961 when Till and McCulloch showed that murine bone marrow cells transplanted into a lethally irradiated mouse could yield colonies in the spleen that could rescue other lethally irradiated mice by recapitulating the entire blood and immune system [5-8]. They established the dual functional criteria to define a stem cell: the capacity to self-renew indefinitely and to differentiate into specialized cells with limited proliferative capacity. The method of choice to demonstrate this was by transplantation of bone marrow cells from one mouse to another lethally irradiated one and demonstrate survival and maintenance of normal bone marrow function. Further, the cells in the reconstituted animal could be serially transplanted and were able to reconstitute another irradiated mouse, demonstrating that the putative stem cells had the capacity to self-renew. All other organ stem cell models need to be interpreted in the light of this gold standard system which has been thoroughly investigated and characterized in animals and humans over the last fifty years.

Stem cell biologists have endeavoured to find subpopulations of cells within the heart and brain that mirror the findings in the hematopoietic system. Specifically, they have tried to identify cells with the capacity to form colonies (e.g. neurospheres), have surface markers known to be expressed on hematopoietic stem cells (e.g. CD34), exhibit functional characteristics of stem cells (e.g. 'side populations' that efflux the Hoechst 33342 dye) and have the ability to differentiate into specific tissue types within an organ. The field of cardiac and neural stem research is at an early stage compared with hematopoietic stem cell biology, but rapid progress has been made in the last decade to elucidate and characterize stem and progenitor cells in the heart and brain.

\section{Evidence for Stem Cells in the Heart}

The traditional view of the heart has been that of a post-mitotic organ given its limited ability to regenerate after injury [9-11]. However, recent studies suggest that the heart has cardiac stem cells with the ability to self-renew and differentiate; the evidence to support this hypothesis and its translational implications has recently been reviewed in depth [12].

One of the earliest reports of cardiac stem cells identified a side population of cells which effluxed the dye Hoechst 33342 [13] using a method that previously identified bone marrow stem cells [14]. The authors showed that approximately $1 \%$ of cardiomyocytes are contained within the side population and have self-renewal and differentiation capacity. This work was extended by Martin et al. [15] in 2004 who found that the side popu- 
lation in murine cardiomyocytes expressed Abcg2, a transporter molecule known to efflux the Hoechst dye. These cells were capable of proliferation and subsequent expression of alpha-actinin, indicating the ability to differentiate.

Another approach in identifying stem cells is to detect their ability to form self-adherent colonies termed 'spheres'. This approach was used by Messina et al. [16] to isolate undifferentiated cardiac cells that grow as self-adherent clusters termed 'cardiospheres' (CS) from postnatal atrial or ventricular human specimens and from murine heart tissue. The CS cells were clonally derived and under certain culture conditions would exhibit synchronous beating. Further, the CS cells expressed the cell markers, CD34, C-Kit and Sca-1, reminiscent of markers defining hematopoietic stem cells. After transplantation of CS cells into the hearts of immunodeficient mice with induced myocardial infarction, CS cells were able to integrate into the myocardium and differentiate. This was also the first demonstration that myocardium from human biopsy specimens could have stem cells extracted and amplified manyfold in vitro, an important finding for the translation of cardiac stem cell therapies.

Using known stem cell markers from the hematopoietic system, attempts were made to isolate candidate stem cell populations from the heart with cell sorting techniques followed by in vitro and in vivo culture techniques. The murine stem cell marker Sca-1+ was detected on $0.3 \%$ of cardiomyocytes from adult mice and these cells could be differentiated into beating cardiomyocytes in vitro by treating them with oxytocin [17]. This study was the first to show that adult cardiac stem cells proliferate and differentiate into various types of cells, including beating cardiomyocytes in vitro.

Studies of murine fetal development have also contributed to the understanding of cardiac stem cells. Two recent studies have characterized fetal murine epicardial progenitor cells that express WT1 [18] or Tbx18 [19] which can differentiate to the cardiomyocyte lineage. As developmental hierarchies within cardiomyocyte development are identified and characterized it will allow for both a better understanding of the biology of cardiac development and also potentially lead to the identification of populations of cells in the adult heart that might be of importance in cardiac regeneration.

These and other results provide some evidence for primitive cardiac cells in the adult capable of differentiation into functional cardiomyocytes. However, none of the studies employed the gold standard for self-renewal capacity by demonstrating that the putative cardiac stem cell could reconstitute tissue and then be serially transplanted into another animal leading to further reconstitution of cardiac tissue. It must be acknowledged that this standard is much more difficult to achieve in the study of solid organ stem cells compared with studies of bone marrow. However, it is possible using green fluorescent protein (GFP) transgenic animals to perform such experiments and these studies will be required for definitive confirmation of stem cell self-renewal.

\section{Evidence for Stem Cells in the Brain}

The first report of a potential neural stem cell was in 1992 when Reynolds et al. [20] isolated a rare population $(0.1 \%)$ from adult murine striatum that could proliferate and generate multipotent clones of cells termed neurospheres and differentiate into neurons, astrocytes and oligodendrocytes in vitro. These candidate neural stem cells expressed the protein nestin. This report established the ability of a candidate neural stem cell to differentiate and thus meet part of the criteria to be classified as a stem cell. It was not until 1996 that the second criterion for stem cells, self-renewal, was established. Among cells from adult mouse striatum, only $1 \%$ had the capacity to form neurospheres and lacked markers of differentiation [21]. Cells from a given neurosphere were then separated and recultured, leading to development of several neurospheres indicating proliferation of the stem cell fraction. This process could be repeated generating tertiary neurospheres with identical properties to the original neurospheres. Further assessment of the neurosphere-derived cells showed MAP-2-, GFAP-, and 04-IR-positive cells, indicating differentiation. Despite the ability to isolate clonogenic neurosphere cells, the neural stem cell could not be identified based on cell surface markers.

Using fluorescent activated cell sorting (FACS) to sort single cells, CD133-positive neural cells were subsequently shown to enrich the neurosphere-forming cells to 5$10 \%$, while the CD133 - fraction could not form neurospheres [22]. The CD133+ cells could self-renew, increased their numbers 1,000-fold over five passages and also produced differentiated neural cells. The CD133+ cells also engrafted, proliferated and differentiated when implanted into the brains of NOD/SCID mice and were detected one year later, while the CD133 - cells could not engraft. These data suggest that neural stem cells can be isolated from specific brain tissues. Again, the only technical standard of 'stemness' not accomplished in this system 
was serial transplantation of engrafted neural stem cells into subsequent NOD/SCID mice leading to further longterm engraftment of neural stem cells.

\section{Hematopoietic Stem Cell Transplantation - the Translational Research Model}

The cell surface markers to identify and isolate hematopoietic stem cells became specific enough to pave the way for the development of both allogeneic and autologous bone marrow transplantation in the treatment of cancer and a wide variety of benign hematologic and metabolic diseases. Specifically, autologous harvest using cryopreservation followed by reinfusion of a patient's own hematopoietic cells after high-dose chemotherapy has become standard therapy for numerous cancers, including lymphoma and multiple myeloma with limited applications for leukemia. Allogeneic transplantation using HLAmatched related and unrelated donors has provided cures for patients with acute myeloid leukemia, chronic myeloid leukemia and aplastic anemia. The application of autologous hematopoietic cell transplantation to cancer focused on the ability to intensify chemotherapy beyond the doselimiting toxicity which was typically bone marrow suppression leading to life threatening anemia, thrombocytopenia and infection. In the case of allogeneic transplantation, in addition to dose-intensification, there was the added benefit of immune cells in the graft ( $\mathrm{T}$ cells and NK cells) to mediate a graft-versus-leukemia effect, further enhancing therapeutic efficacy. Only in the treatment of aplastic anemia is the replenishing capacity of hematopoietic stem cells the primary therapeutic application of the transplant. Given that potential stem cell populations have been demonstrated in the brain and heart, the treatment of numerous diseases with tissue-specific stem cells capable of reconstituting an injured or degenerated tissue becomes a conceivable possibility. However, as discussed previously, the biology of solid organ stem cells still lags behind the understanding of hematopoietic stem cells that allowed for the development of clinically applicable hematopoietic stem and progenitor cell transplantation. Therefore, the use of endogenous tissue stem cells from a patient's own heart that could be stimulated or expanded and used for therapy is beyond current phase I studies. The same limitation exists for the application of neural stem cells for therapy. Therefore, a variety of alternative cell sources have been tested with the intent that the cellular agent functions as a stem cell, progenitor, or differentiated cell to correct the deficient tissue.

Cell Therapy for Age-Related Disorders

\section{Sources of Cells for Therapeutic Use}

Before discussing cell therapies for cardiovascular and neurological diseases, the available cellular agents must be briefly reviewed. Potential therapeutic cellular agents fall into several broad categories: (1) bone marrow-derived cells; (2) endogenous organ-specific stem and progenitor cells; (3) embryonic stem cells; (4) cell lines, and (5) gene-modified somatic cells that function as stem cells. Most clinical studies have used bone marrow-derived cells either directly harvested or effluxed from the bone marrow space using G-CSF and collected using apheresis techniques. Both of these methods lead to a collection of mixed cell populations consisting of stem cells and a hierarchy of progenitors. The best terminology to refer to cells used in most of these studies are 'hematopoietic stem and progenitor cells' (HSPC) as it includes both stem cells and differentiated progeny that may contribute to clinical efficacy [23]. We reserve the term hematopoietic stem cell (HSC) to refer to highly purified stem cell populations.

Bone marrow cells other than HSPC have been investigated as therapeutic agents for regenerative medicine including mesenchymal stromal cells (MSC) which has been recently reviewed in depth [24]. Minimum criteria for defining MSC have been defined as bone marrow cells that are plastic adherent under standard culture conditions, express CD105, CD73 and CD90, but lack expression of CD45, CD34, CD14, CD11b, CD79, CD19 and HLA-DR and are able to differentiate into osteoblasts, adipocytes and chondroblasts in vitro [25]. The 'stemness' of MSCs has been hotly debated and current nomenclature refers to them as mesenchymal stromal cells (MSCs) because the putative MSC stem cell has not been fully characterized. However, a recent report finds that CD271 $1^{\text {bright }}$ bone marrow cells are highly enriched for MSC stem cell capacity [26]. This opens the door to more sophisticated cell therapeutic interventions using MSC in the future.

Embryonic stem cells (ESC) are the most controversial source of stem cells for regenerative medicine and significant restrictions have been placed on their use in numerous countries for ethical reasons. ESC are derived from the inner mass of the blastocyst $[27,28]$. Some embryonic cell lines are approved for experimental use and demonstrate the potential to differentiate into any tissue type in the body given the right environmental cues. Specifically, ESC have been shown to differentiate into cardiomyocyte-like cells with the capacity to 'beat' like functional myocardium. However, implantation of ESC can 
lead to teratoma formation $[29,30]$ making them problematic as therapeutic agents. Therefore, some form of differentiation may be required to use these cells therapeutically. In fact, ESC have been partially differentiated in vitro before implantation in the injured heart in animal models [31, 32].

Striking work done by Takahashi et al. [33, 34] demonstrated that murine and human fibroblast cells could revert to an embryonic-like state by transducing four genes (Oct 3/4, Sox2, cMyc and Klf4) into the cells. This important proof of principle experiment provides a potential method to bypass many of the ethical issues surrounding the use of human embryonic stem cells. While the approach is at a very early stage, it may facilitate the creation of histocompatible stem cells from a patient's own somatic cells for regenerative purposes.

Cell lines also have potential for use as cellular agents, but most are permanent malignant lines and, as such, may carry serious risks introducing active malignancy into the recipient. A teratoma cell line, however, has been used in an animal model of stroke which, when transplanted, did not develop into a tumor and led to improved learning in the animals compared with untreated controls [35]. This approach has been extended to patients with stroke using a similar type of teratoma line implanted stereotactically into the brain of patients with stroke $[36,37]$.

\section{Clinical Trials of Cell Therapy for Myocardial Infarction}

A systematic review of the literature using Medline was done to identify all studies of cell therapies for myocardial infarction using the following strategy: (1) 'myocardial infarction' (explode) as a key word and (2) 'stem cell' (explode) or 'tissue therapy' (explode) or 'cell therapy' as a key word to yield trials of cell therapy. (3) Combine results from 1 and 2 using the 'and' function, (4) limit to 'clinical trial-all' and 'humans'. This yielded 87 articles that were manually reviewed and studies were further excluded if: (1) condition treated was not myocardial infarction (e.g. angina); (2) the article only reported safety data (e.g. true phase I); (3) stem cell mobilization was not done using pharmacologic method (e.g. exercise induced); (4) clinically relevant outcomes were not reported (e.g. tracking stem cell numbers in peripheral blood as primary outcome), and (5) preliminary results were reported in the same clinical trial reported at a later date with more complete data (e.g. TOPCARE-AMI trials published 2002 and 2004). This yielded 37 papers which upon critical review yielded 23 studies that used randomization between control and treatment groups and were included for further evaluation. Six additional randomized trials that met criteria were identified in reviews or references of other clinical trials yielding a total of 29 studies of interest. Only one randomized study of surgical approaches was found and several non-randomized surgical studies using cellular agents were identified and included for a brief discussion regarding the use of direct intramyocardial injection as a mode of cellular delivery.

The majority of clinical trials testing cell therapy for myocardial infarction involved autologous bone marrow-derived HSPC either derived directly from bone marrow or from the peripheral blood following G-CSF mobilization. G-CSF was identified more than 20 years ago [38] and facilitates efflux of stem cells from the bone marrow into the peripheral circulation by activating neutrophil elastases, which then cleaves membrane-bound SDF-1 on stromal cells in the bone marrow disrupting the interaction between SDF-1 and the CXCR-4 receptor on the HSC [39, 40, 41]. HSC are either mobilized and allowed to traffic to the site of MI by normal circulatory methods after percutaneous coronary intervention (PCI) such as balloon angioplasty or stenting, while others involved collection of hematopoietic cells and direct infusion into the coronary circulation using PCI.

Trials of G-CSF alone were attempted given that this was a well-established therapeutic agent used in bone marrow transplantation to mobilize stem/progenitor cells for peripheral harvest by apheresis. The first trial of G-CSF alone for MI randomized twenty patients to receive either $5 \mu \mathrm{g} / \mathrm{kg}$ of G-CSF for 4 days or placebo and showed no significant improvement in cardiac function. LVEF and LVEDV improved, but were just shy of statistical significance [42]. Subsequently, a larger randomized trial of G-CSF of 50 patients showed improvements at 30 days and 4 months in wall motion, left ventricular ejection fraction and several other parameters [43]. However, three large double-blind randomized clinical trials termed G-CSF-STEMI, STEMMMI and REVIVAL-2 did not show any benefit for G-CSF [44-46]. Table 1 summarizes all the randomized trials to date of stem cell mobilization strategies for the treatment of MI and shows that the majority of large clinical trials did not show improvement in clinical parameters.

Other investigators looked at directly infusing the cells into the coronary circulation using PCI to improve delivery to the site of injury. Numerous early studies in 2004 showed preliminary evidence of efficacy of direct 
Table 1. Randomized controlled clinical trials of G-CSF for MI

\begin{tabular}{|c|c|c|c|c|}
\hline Author, year [ref.] (trial name) & Patients & Type of MI & Intervention & Key statistically significant effects \\
\hline $\begin{array}{l}\text { Leone et al., } 2007 \text { [73] } \\
\text { (The Rigenera study) }\end{array}$ & 41 & anterior wall MI & $\mathrm{PCI}+\mathrm{G}-\mathrm{CSF}$ & $\begin{array}{l}\operatorname{LVEF}(\mathrm{p}=0.02) \text { and LVED }(\mathrm{p}=0.04) \text {, ventricular dilation } \\
\text { improved at } 5 \text { months in the treatment group }\end{array}$ \\
\hline Takano et al., 2007 [74] & 40 & LADMI & $\mathrm{PCI}+\mathrm{G}-\mathrm{CSF}$ & $\begin{array}{l}\text { LVEF at } 6 \text { months was significantly better in the G-CSF group } \\
(p=0.013) \text { but not changed in the control group }(p=0.245) \\
\text { relative to baselines }\end{array}$ \\
\hline Malafronte et al., 2007 [75] & 13 & $\begin{array}{l}\text { first anterior STEMI } \\
\text { with LV dysfunction }\end{array}$ & $\mathrm{PCI}+\mathrm{G}-\mathrm{CSF}$ & none \\
\hline Ellis et al., 2006 [76] & 18 & large AMI & G-CSF & none \\
\hline Deng et al., 2006 [77] & 20 & AMI & $\mathrm{PCI}+\mathrm{GM}-\mathrm{CSF}$ & $\begin{array}{l}\text { LVEF at } 12 \text { months was improved in the treatment group } \\
(\mathrm{p}<0.05)\end{array}$ \\
\hline $\begin{array}{l}\text { Engelmann et al., } 2006 \text { [44] } \\
\text { (G-CSF-STEMI) }\end{array}$ & 44 & $\begin{array}{l}\text { late revascularized } \\
\text { subacute STEMI }\end{array}$ & $\mathrm{PCI}+\mathrm{G}-\mathrm{CSF}$ & none \\
\hline Ripa et al., 2006 [45] (STEMMI) & 78 & STEMI & $\mathrm{PCI}+\mathrm{G}-\mathrm{CSF}$ & none \\
\hline $\begin{array}{l}\text { Zohlnhofer et al., } 2006 \\
\text { [46] (REVIVAL-2) }\end{array}$ & 114 & STEMI & $\mathrm{PCI}+\mathrm{G}-\mathrm{CSF}$ & none \\
\hline Valgimigli et al., 2005 [42] & 20 & STEMI & $\mathrm{PCI}+\mathrm{G}-\mathrm{CSF}$ & none \\
\hline $\begin{array}{l}\text { Ince et al., } 2005 \text { [43] } \\
\text { (FIRSTLINE-AMI) }\end{array}$ & 50 & STEMI & $\mathrm{PCI}+\mathrm{G}-\mathrm{CSF}$ & $\begin{array}{l}\text { at } 4 \text { months improvements seen in the treated group for LVEF } \\
(\mathrm{p}<0.001)\end{array}$ \\
\hline
\end{tabular}

PCI = Percutaneous coronary intervention; G-CSF = granulocyte colony-stimulating factor; AMI = acute myocardial infarction; LADMI = left anterior descending myocardial infarction; STEMI = ST elevated myocardial infarction; LVEF = left ventricular ejection fraction.

infusion of stem cells into the coronary blood supply as measured by improved LVEF [47-49]. One study used MSCs expanded ex vivo followed by reinfusion into the coronary circulation and also showed significant improvement in LVEF [50]. The MAGIC Cell 1 trial of GCSF versus intracoronary (IC) infusion of peripherally harvested G-CSF mobilized HSPC showed that only the IC infusion group showed improved LVEF at 6 months and a maintained benefit at two years [51]. Further, on aggregate, most studies showed that localized administration of harvested HSPC using PCI is more effective than mobilizing with cytokines and relied on the conventional circulation system to carry the cells to the site of infarction (tables 1,2). Only the REPAIR-AMI study reported on more clinically relevant outcomes. Specifically, they demonstrated that the combined endpoints of death, recurrence of MI and rehospitalization for heart failure was reduced in the group treated with IC infusion of bone marrow-derived HSPC [52]. The first systematic review and meta-analysis of HSPC for cardiac repair identified eighteen eligible studies on acute MI and ischemic cardiomyopathy, twelve of which were randomized, and concluded that LVEF improved by $3.66 \%(\mathrm{p}<0.001)$ in patients receiving cell therapy [53]. Further, a recently published systematic review and meta-analysis of thirteen randomized trials of HSPC for acute MI determined that overall cell therapy improved LVEF by $2.99 \%$ in the treatment patients relative to controls $(\mathrm{p}=0.0007)$ [54].

Surgeons also have looked at direct injection of cells into injured myocardium. A phase I study of intracardiac injection of skeletal myoblasts into patients with previous MI reported improvements in LVEF and other parameters [55]. However, a follow-up randomized, multicenter study, placebo-controlled, double-blind study of autologous skeletal myoblasts involving 120 patients (90 treated) did not demonstrate any benefit [56]. Intracardiac injection of CD133+ enriched bone marrow-derived HSPC in patients with MI being treated with coronary artery bypass grafting (CABG) led to improvements in LVEF in $4 / 5$ patients and infarct tissue perfusion improved in 5/5 at 3-9 months [57]. One study looked at patients with an old MI and following reperfusion surgery injected of GCSF mobilized CD34+ enriched HSPC directly into the myocardium. Improvements in LFEV were noted at 28 and 52 weeks [58]. The MAGNUM study enrolled 15 patients to receive direct injection of peripherally harvested 
Table 2. Randomized controlled clinical trials using PCI directed delivery of cellular agents directly into the coronary circulation after MI

\begin{tabular}{|c|c|c|c|c|}
\hline Author, year [ref.] (trial name) & Patients & Type of MI & Intervention & Key statistically significant effects \\
\hline Li et al., 2007 [78] & 70 & AMI & $\begin{array}{l}\text { PCI + IC } \\
\text { PBHSPC vs. PCI alone }\end{array}$ & $\begin{array}{l}\text { significant improvement in LVEF from baseline } \\
(\mathrm{p}<0.0001)\end{array}$ \\
\hline $\begin{array}{l}\text { Kang et al., 2007 [51] } \\
\text { (MAGIC Cell 1) }\end{array}$ & 30 & AMI and OMI & $\begin{array}{l}\text { PCI + IC PBHSPC vs. } \\
\text { PCI + G-CSF vs. PCI alone }\end{array}$ & $\begin{array}{l}\text { improvement in IC infusion group vs. G-CSF } \\
\text { mobilization with respect to LVEF, remodeling, } \\
\text { ESV at } 6 \text { months }(\mathrm{p}<0.004) \text { and maintained up to } \\
2 \text { years, but not significant relative to control group }\end{array}$ \\
\hline $\begin{array}{l}\text { Lunde et al., } 2007 \text { [79] } \\
\text { (ASTAMI) }\end{array}$ & 100 & AMI & PCI + BMC vs. PCI alone & improved exercise time $(\mathrm{p}<0.01)$ and peak heart rate \\
\hline Suarez de Lezo et al., 2007 [80] & 30 & AMI & $\begin{array}{l}\text { PCI + IC BMC vs. } \\
\text { G-CSF }\end{array}$ & $\begin{array}{l}20 \% \text { increase in mean EF in IC BMC group vs. G-CSF } \\
(\mathrm{p}<0.01) \text { and/or control }(\mathrm{p}<0.05)\end{array}$ \\
\hline Tatsumi et al., 2007 [81] & 54 & STEMI & $\begin{array}{l}\text { PCI + IC PBMNC vs. PCI } \\
\text { alone }\end{array}$ & $\begin{array}{l}\text { LVEF increased } 7.4 \% \text { in control vs. } 13.5 \% \text { in treatment } \\
\text { group at } 6 \text { months }(p=0.037)\end{array}$ \\
\hline $\begin{array}{l}\text { Schachinger et al., } 2006 \text { [52] } \\
\text { (REPAIR-AMI) }\end{array}$ & 204 & AMI & PCI + IC BMC vs. PCI alone & $\begin{array}{l}\text { combined endpoint of death, recurrence of } \mathrm{MI} \text { and } \\
\text { rehospitalization for heart failure was reduced in } \\
\text { treatment group }(\mathrm{p}=0.006)\end{array}$ \\
\hline $\begin{array}{l}\text { Kang et al., } 2006 \text { [82] } \\
\text { (MAGIC Cell-3-DES) }\end{array}$ & 96 & AMI and OMI & PCI + IC PBHSPC vs. PCI alone & $\begin{array}{l}\text { only AMI showed improved LVEF and remodeling } \\
(\mathrm{p}<0.05)\end{array}$ \\
\hline Yao et al., 2006 [83] & 184 & AMI & PCI IC BMC vs. PCI alone & none; no adverse effects noted \\
\hline Assmus et al., 2006 [84] & 75 & OMI & $\mathrm{PCI}+\mathrm{IC} \mathrm{BMC}$ or $\mathrm{CPC}$ & $\begin{array}{l}\text { LVEF was improved in in patients receiving BMC } \\
\text { relative to control }(\mathrm{p}<0.001) \text { and } \mathrm{CPC}(\mathrm{p}<0.003)\end{array}$ \\
\hline $\begin{array}{l}\text { Meyer et al., } 2006 \text { [85] } \\
\text { (BOOST) }\end{array}$ & 60 & AMI & PCI + IC BMC vs. PCI alone & $\begin{array}{l}\text { LVEF improved at } 6 \text { months, but did not maintain benefit } \\
\text { relative to control at } 18 \text { months in long-term follow-up }\end{array}$ \\
\hline Janssens et al., 2006 [86] & 67 & STEMI & PCI + IC BMC vs. PCI alone & BMSC groups had decreased infarct size $(\mathrm{p}=0.036)$ \\
\hline $\begin{array}{l}\text { Ge et al., } 2006 \text { [87] } \\
\text { (TCT-STAMI) }\end{array}$ & 20 & AMI & PCI + IC BMC & $\begin{array}{l}\text { LVEF improved from baseline at } 6 \text { months in the } \\
\text { treatment group, but not in the control }(\mathrm{p}<0.05)\end{array}$ \\
\hline Huang et al., 2006 [88] & 40 & AMI & PCI + IC BMC vs. PCI alone & $\begin{array}{l}\text { LVEF improved to a great degree in the treatment group } \\
\text { relative to control }(\mathrm{p}=0.047)\end{array}$ \\
\hline Karpov et al., 2005 [89] & 44 & AMI & PCI + IC BMC vs. PCI alone & none; LVEF did not improve relative to control \\
\hline Meluzin et al., 2006 [90] & 66 & AMI & $\begin{array}{l}\mathrm{PCI}+\mathrm{IC} \text { BMC }(10 \mathrm{e} 7) \\
\text { vs. PCI + IC BMC (10e8) vs. } \\
\text { PCI alone }\end{array}$ & $\begin{array}{l}\text { LVEF at } 3 \text { months was improved in the high-dose group } \\
\text { (10e8) relative to control }\end{array}$ \\
\hline Penicka et al., 2006 [91] & 27 & AMI & PCI + BMC vs. PCI alone & $\begin{array}{l}\text { none; no improvement in LVEF; } 2 \text { patients with serious } \\
\text { complications during or after bone marrow harvest; } \\
\text { trial terminated early }\end{array}$ \\
\hline Ruan et al., 2005 [92] & 20 & AMI & PCI + IC BMC vs. PCI alone & $\begin{array}{l}\text { LVEF }(p<0.05) \text {, EDV and ESV }(p<0.05) \text { were improved } \\
\text { in treatment group }\end{array}$ \\
\hline $\begin{array}{l}\text { Schachinger et al., } 2004 \text { [93] } \\
\text { (TOPCARE-AMI) }\end{array}$ & 59 & AMI & PCI + IC CPC vs. PCI + IC BMC & $\begin{array}{l}\text { good safety profile for both } \mathrm{CPC} \text { and } \mathrm{BMC} \text { and } \\
\text { equivalent improvement in LVEF at } 4 \text { months from } \\
\text { baselines }(\mathrm{p}<0.001)\end{array}$ \\
\hline Chen et al., 2004 [50] & 69 & AMI & PCI + IC MSC vs. PCI alone & LVEF increased in treatment group $(\mathrm{p}<0.05)$ \\
\hline
\end{tabular}

PCI = Percutaneous coronary intervention; G-CSF = granulocyte colony-stimulating factor; AMI = acute myocardial infarction; OMI = old myocardial infarction; STEMI = ST elevated myocardial infarction; $\mathrm{LVEF}=$ left ventricular ejection fraction; $\mathrm{BMC}=$ primary harvested mononuclear bone marrow cells; PBHSPC = peripheral blood derived G-CSF mobilized hematopoietic stem and progenitor cells; IC = intracoronary infusion; PBMNC = peripheral blood mononuclear cells collected without G-CSF stimulation; CPC = circulating progenitor cells; MSC = mesenchymal stromal cells. 
autologous mononuclear bone marrow cells into the scar in addition to application of a 3D collagen type I matrix [59]. In a follow-up study by the same group in 20 consecutive patients with left ventricular postischemic myocardial scars 10 were treated with autologous mononuclear bone marrow cells with and without collagen matrix support and both groups improved from baseline LVEF, but there was no difference between groups [60]. They reported that the New York Heart Association Functional Class improved from 2.3 to $1.4(\mathrm{p}=0.005)$ relative to baseline in these patients.

\section{Clinical Trials of Cell Therapy for Stroke}

A systematic review of the literature using Medline was done to identify all studies of cell therapies for stroke by the following search strategy: (1) 'stroke' (explode) as key word and (2) 'stem cell' (explode) or 'tissue therapy' (explode) or 'cell therapy' as a key word to yield trials of cell therapy. (3) Combine results from 1 and 2 using the 'and' function, (4) limit to 'clinical trial all' and 'human'. This yielded 42 articles which following manual review yielded only 4 studies of relevance. One further study was found from the reference section of a recent review yielding five studies.

The first clinical trials of cell transplantation for neurologic disease were with autologous adrenal medullary grafts into the striatum in Parkinson's patients [61]. Subsequently, fetal mesencephalic dopamine-producing cells were transplanted into the caudate and putamen of a patient with late stage Parkinson's disease [62]. Numerous larger trials have since been done using this approach. Of note, Freed et al. [63] performed a randomized trial with a sham surgery control group demonstrating significant improvement in patients under 60 and evidence of engraftment of fetal tissue using PET scan or postmortem examination. However, this methodology has led to significant problems with dystonia and dyskinesias in this and other studies as reviewed by Hagell et al. [64]. Despite the problems encountered, the methods developed for stereotactic cellular treatments of Parkinson's disease have been applied to other neurologic diseases, including stroke. However, the focus has been on alternatives to fetal neural tissue for cell therapy.

The teratoma cell line NT2/D1, able to be differentiated into neurons by the addition of $10 \mu \mathrm{M}$ retinoic acid (termed LBS-Neurons developed by Layton BioScience), has remarkably entered clinical trials. In a phase I study these neurons were stereotactically transplanted into the basal ganglia of 12 patients with basal ganglia stroke and fixed motor deficits [36]. No toxicities or tumor formation were seen with this approach and there was a statistically significant improvement in patients as assessed by the European Stroke Scale (ESS).

Subsequently, Kondziolka et al. [37] proceeded with a phase II randomized study of LBS neurons for patients with subcortical motor stroke. In this study 18 patients with fixed motor deficits stable for at least 2 months were randomized at two different centers to receive two different doses of LBS neurons (7 patients per dose level) with non-surgical controls (4 patients). Although there was no overall improvement at 6 months in the treatment groups on the ESS, the Action Research Arm Test gross hand movement scores improved compared with the control group $(p=0.017)$ and baseline $(p=0.01)$. Further, the Stroke Impact Scale improved relative to baseline ( $\mathrm{p}=$ $0.045)$ as well as the Everyday Memory Test score ( $\mathrm{p}=$ $0.004)$. There were no surgical complications in the 14 patients who underwent cell transplantation. Several statistically significant improvements were observed for gross hand movement scores from baseline and compared with controls.

In a recent review, Kondziolka et al. [65] discuss their current surgical approach to stroke and new cellular agents that have potential for better efficacy in treating stroke. ReNeuron Group has developed a cell line CTX0E03 from fetal neural stem cells for the treatment of stable ischemic stroke with application to the FDA for phase I trials. These cells require a growth factor to continue proliferation, but when withdrawn differentiate into neurons. SanBio Inc. has developed SanBio 623 cells by transient transfection of bone marrow stromal cells with a plasmid encoding human Notch intracellular domain (NICD) protein. The gene-modified cells do not differentiate into adipose or bone tissue [65], and culturing with appropriate trophic factors causes differentiation into neural tissue [66].

An alternative approach using fetal neural stem cells mixed with fetal liver cells primarily of hematopoietic origin in a 10:1 ratio delivered by lumbar puncture was developed by Rabinovich et al. [67]. Ten patients with old hemorrhagic or ischemic stroke with fixed stable deficits were treated with stem cells and compared to 11 comparably affected controls selected retrospectively. Positive changes were reported in all patients receiving cellular therapy as measured by quality of life indicators, but formal statistical analysis was not done.

A trial of G-CSF in 36 patients to mobilize stem cells has demonstrated, similar to the trials in cardiac patients, 
that in stroke patients G-CSF can be used to mobilize CD34+ cells approximately 15 fold from baseline levels into the peripheral circulation [68]. No adverse events were noted. Clinical outcomes were not measured in this study. In a small blinded randomized controlled trial of patients with middle cerebral artery stroke seven patients were treated with G-CSF with three controls. At 12month follow-up, the G-CSF group showed statistically significant improvements in four different stroke assessment scales. Given the small patient numbers a larger scale clinical trial is warranted. Recently, published studies in murine models of stroke (middle cerebral artery occlusion) showed that G-CSF treated rats had smaller infarcts, better functional outcomes [69], increased angiogenesis [70] and the presence of bone marrow-derived endothelial cells in new blood vessels that had formed in the infarct territory [71]. These animal studies provide interesting mechanistic possibilities for this type of therapeutic approach in humans.

There has been one randomized study of culture-expanded autologous mesenchymal stromal cells of $30 \mathrm{pa}-$ tients with cerebral infarcts within the middle cerebral arterial territory and with severe neurological deficits [72]. Only five patients received $100 \times 10^{6}$ culture-expanded MSCs IV while 25 other patients served as controls. Outcomes improved in MSC-treated patients compared with the control patients as measured by the Barthel Index and Rankin Score at 3 and 6 months, but differences were not statistically significant at 12 months. No significant toxicities were identified. This small study provides promising evidence for the use of MSC in stroke, which needs to be verified in a larger trial. Whether MSC could be more effective if stereotactically implanted into the region of stroke is a question that has not been addressed. These studies represent the first therapeutic trials involving cell therapy for stroke and are encouraging, given the measurable improvements in some cases.

\section{Summary and Conclusion}

Hematopoietic stem and progenitor cell therapies have been shown to improve cardiac hemodynamic function such as left ventricular ejection fraction when administered via the coronary artery. Only one study addressed clinically relevant outcomes such as survival and recurrence of MI or rehospitalization. Emerging studies of MSC delivered intravenously and cell line therapies using stereotactic implantation for stroke also show particular promise. Further biological studies and large-scale clinical studies are warranted to determine the mechanism by which these therapies work and to confirm efficacy.

\section{Acknowledgements}

B.A.W. is a supported by a Terry Fox Foundation Clinical Research Fellowship through an award from the National Cancer Institute of Canada.

A.K. holds the Gloria and Seymour Epstein Chair in Cell Therapy at University Health Network and the University of Toronto.

\section{References}

1 Arking R: Biology of Aging: Observations and Principles, ed 2. Sunderland, Sinauer Associates, Inc., 1998, p 10.

2 Rosamond W, Flegal K, Friday G, Furie K, Go A, Greenlund K, Haase N, Ho M, Howard V, Kissela B, Kittner S, Lloyd-Jones D, McDermott M, Meigs J, Moy C, Nichol G, O'Donnell CJ, Roger V, Rumsfeld J, Sorlie P, Steinberger J, Thom T, Wasserthiel-Smoller S, Hong Y: Heart disease and stroke statistics - 2007 update: a report from the American Heart Association Statistics Committee and Stroke Statistics Subcommittee. Circulation 2007;115:e69-e171.

3 Callow AD: Cardiovascular disease 2005 the global picture. Vascular Pharmacology 2006;45:302-307.
4 WHO: World Health Statistics Part 1: Ten highlights in health statistics 2008, p 29. (Website: http://www.who.int/whosis/whostat/EN_WHS08_Part1.pdf).

$\checkmark 5$ Till JE, McCulloch CE: A direct measurement of radiation sensitivity of normal mouse bone marrow cells. Radiat Res 1961; 14:213-222.

6 6 Becker AJ, McCulloch EA, Till JE: Cytological demonstration of the clonal nature of spleen colonies derived from transplanted mouse marrow cells. Nature 1963;197:452454.

7 Siminovitch L, McCulloch EA, Till JE: The distribution of colony-forming cells among spleen colonies. J Cell Physiol 1963;62:327336.
-8 Till JE, McCulloch EA, Siminovitch L: A stochastic model of stem cell proliferation, based on the growth of spleen colony-forming cells. Proc Natl Acad Sci USA 1964;51: 29-36.

-9 Agah R, Kirshenbaum LA, Abdellatif M, Truong LD, Chakroborty S, Michael LH, Schneider MD: Adenoviral delivery of E2F-1 directs cell cycle reentry and p53-independent apoptosis in postmitotic adult myocardium in vivo. J Clin Invest 1997; 100:27222728.

10 Chien KR, Olson EN: Converging pathways and principles in heart development and disease. Cell 2002;110:153-162.

11 MacLellan WR, Schneider MD: Genetic dissection of cardiac growth control pathways. Annu Rev Physiol 2000;62:289-319. 
12 Leri A, Kajstura J, Anversa P, Frishman WH: Myocardial regeneration and stem cell repair. Curr Probl Cardiol 2008;33:91-153.

13 Hierlihya AM, Sealea P, Lobeb CG, Rudnickia MA, Megeneya LA: The post-natal heart contains a myocardial stem cell population. FEBS Letters 2002;530:239-243.

14 Goodell M, Brose K, Paradis G, Conner AS, Mulligan R: Isolation and functional properties of murine hematopoietic stem cells that are replicating in vivo. J Exp Med 1996;183: 1797-1806.

15 Martin CM, Meeson AP, Robertson SM, Hawke TJ, Richardson JA, Bates S, Goetsch SC, Gallardo TD, Garry DJ: Persistent expression of the ATP-binding cassette transporter, Abcg2, identifies cardiac SP cells in the developing and adult heart. Dev Biol 2004;265:262-275.

16 Messina E, De Angelis L, Frati G, Morrone S, Chimenti S, Fiordaliso F, Salio M, Battaglia M, Latronico MV, Coletta M, Vivarelli E, Frati L, Cossu G, Giacomello A: Isolation and expansion of adult cardiac stem cells from human and murine heart. Circ Res 2004;95:911-921.

17 Matsuura K, Nagai T, Nishigaki N, Oyama T, Nishi J, Wada H, Sano M, Toko H, Akazawa H, Sato T, Nakaya H, Kasanuki H, Komuro I: Adult cardiac Sca-1-positive cells differentiate into beating cardiomyocytes. J Biol Chem 2004;279:11384-11391.

18 Zhou B, Ma Q, Rajagopal S, Wu SM, Domian I, Rivera-Feliciano J, Jiang D, von Gise A, Ikeda S, Chien KR, Pu WT: Epicardial progenitors contribute to the cardiomyocyte lineage in the developing heart. Nature 2008; 454:109-113.

19 Cai CL, Martin JC, Sun Y, Cui L, Wang L, Ouyang K, Yang L, Bu L, Liang X, Zhang X, Stallcup WB, Denton CP, McCulloch A, Chen J, Evans SM: A myocardial lineage derives from Tbx18 epicardial cells. Nature 2008;454:104-108.

20 Reynolds BA, Weiss S: Generation of neurons and astrocytes from isolated cells of the adult mammalian central nervous system. Science 1992;255:1707-1710.

-21 Gritti A, Parati EA, Cova L, Frolichsthal P, Galli R, Wanke E, Faravelli L, Morassutti DJ, Roisen F, Nickel DD, Vescovi AL: Multipotential stem cells from the adult mouse brain proliferate and self-renew in response to basic fibroblast growth factor. J Neurosci 1996; 16:1091-1100.

22 Uchida N, Buck DW, He D, Reitsma MJ, Masek M, Phan TV,Tsukamoto AS, Gage FH, Weissman IL: Direct isolation of human central nervous system stem cells. Proc Natl Acad Sci USA 2000;97:14720-14725.

-23 Shizuru JA, Negrin RS, Weissman IL: Hematopoietic stem and progenitor cells: Clinical and preclinical regeneration of the hematolymphoid system. Annu Rev Med 2005;56: 509-538.

-24 Keating A: Mesenchymal stromal cells. Curr Opin Hematol 2006;13:419-425.
25 Dominici M, Le Blanc K, Mueller I, SlaperCortenbach I, Marini F, Krause D, Deans R, Keating A, Prockop DJ, Horwitz E: Minimal criteria for defining multipotent mesenchymal stromal cells. The International Society for Cellular Therapy position statement. Cytotherapy 2006;8:315-317.

26 Bühring HJ, Battula VL, Treml S, Schewe B, Kanz L, Vogel W: Novel markers for the prospective isolation of human MSC. Ann NY Acad Sci 2007;1106:262-271.

27 Odorico JS, Kaufman DS, Thomson JA: Multilineage differentiation from human embryonic stem cell lines. Stem Cells 2001;19: 193-204.

28 Pera MF, Reubinoff B, Trounson A: Human embryonic stem cells. J Cell Sci 2000;113:510.

-29 Reubinoff BE, Pera M, Fong CY, Trounson A, Bongso A: Embryonic stem cell lines from human blastocysts: somatic differentiation in vitro. Nat Biotech 2000;18:399-404.

30 Thomson JA, Eldor JI, Shapiro SS, Waknitz MA, Swiergiel JJ, Marshall VS, Jones JM: Embryonic stem cell lines derived from human blastocysts. Science 1998;282:11451147.

31 Kehat I, Khimovich L, Caspi O, Gepstein A, Shofti R, Arbel G, Huber I, Satin J, ItskovitzEldor J, Gepstein L: Electromechanical integration of cardiomyocytes derived from human embryonic stem cells. Nat Biotech 2004; 22:1282-1289.

-32 Yang Y, Min JY, Rana JS, Ke Q, Cai J, Chen Y, Morgan JP, Xiao YF: VEGF enhances functional improvement of post-infarcted hearts by transplantation of ESC-differentiated cells. J Appl Physiol 2002;93:1140-1151.

33 Takahashi K, Yamanaka S: Induction of pluripotent stem cells from mouse embryonic and adult fibroblast cultures by defined factors. Cell 2006;126:663-676.

34 Takahashi K, Tanabe K, Ohnuki M, Narita M, Ichisaka T, Tomoda K, Yamanaka S: Induction of pluripotent stem cells from adult human fibroblasts by defined factors. Cell 2007;131:861-872.

- 35 Borlongan CV, Tajima Y, Trojanowski JQ, Lee VM-Y, Sanberg PR: Transplantation of cryopreserved human embryonalcarcinoma-derived neurons (NT2N) promotes functional recovery in ischemic rats. Exp Neurol 1998;149:310-321.

36 Kondziolka D, Wechsler L, Goldstein S, Meltzer C, Thulborn KR, Gebel J, Jannetta P, DeCesare S, Elder EM, McGrogan M, Reitman MA, Bynum L: Transplantation of cultured human neuronal cells for patients with stroke. Neurology 2000;55:565-569.

- 37 Kondziolka D, Steinberg GK, Wechsler L, Meltzer CC, Elder E, Gebel J, Decesare S, Jovin T, Zafonte R, Lebowitz J, Flickinger JC, Tong D, Marks MP, Jamieson C, Luu D, BellStephens T, Teraoka J: Neurotransplantation for patients with subcortical motor stroke: a phase 2 randomized trial. J Neurosurg 2005; 103:38-45.
38 Nagata S, Tsuchiya M, Asano LS, Kaziro Y, Yamazaki T, Yamamoto O, Hirata Y, Kubota N, Oheda M, Nomura H, Ono M: Molecular cloning and expression of cDNA for human granulocyte colony-stimulating factor. $\mathrm{Na}-$ ture 1986;319:415-418.

- 39 Lévesque JP, Hendy J, Takamatsu Y, Simmons PJ, Bendall LJ: Disruption of the CXCR4/CXCL12 chemotactic interaction during hematopoietic stem cell mobilization induced by GCSF or cyclophosphamide. J Clin Invest 2003;111:187-196.

40 Lévesque JP, Hendy J, Winkler IG, Takamatsu Y, Simmons PJ: Granulocyte colonystimulating factor induces the release in the bone marrow of proteases that cleave c-KIT receptor (CD117) from the surface of hematopoietic progenitor cells. Exp Hematol 2003;31:109-117.

41 Carion A, Benboubker L, Herault O, Roingeard F, Degenne M, Senecal D, Desbois I, Colombat P, Charbord P, Binet C, Domenech J: Stromal-derived factor 1 and matrix metalloproteinase 9 levels in bone marrow and peripheral blood of patients mobilized by granulocyte colony-stimulating factor and chemotherapy. Relationship with mobilizing capacity of haematopoietic progenitor cells. Br J Haematol 2003;122:918-926.

42 Valgimigli M, Rigolin GM, Cittanti C, Malagutti P, Curello S, Percoco G, Bugli AM, Della Porta M, Bragotti LZ, Ansani L, Mauro E, Lanfranchi A, Giganti M, Feggi L, Castoldi G, Ferrari R: Use of granulocyte-colony stimulating factor during acute myocardial infarction to enhance bone marrow stem cell mobilization in humans: clinical and angiographic safety profile. Eur Heart J 2005;26: $1838-1845$.

43 Ince $\mathrm{H}$, Petzsch $\mathrm{M}$, Kleine $\mathrm{HD}$, Eckard $\mathrm{H}$, Rehders T, Burska D, Kische S, Freund M, Nienaber CA: Prevention of left ventricular remodelling with granulocyte colony-stimulating factor after acute myocardial infarction: final 1-year results of the Front-Integrated Revascularization and Stem Cell Liberation in Evolving Acute Myocardial Infarction by Granulocyte Colony-Stimulating Factor (FIRSTLINE-AMI) Trial. Circulation 2005;112(suppl 9):173-180.

44 Engelmann MG, Theiss HD, Hennig-Theiss C, Huber A, Wintersperger BJ, WerleRuedinger AE, Schoenberg SO, Steinbeck G, Franz WM: Autologous bone marrow stem cell mobilization induced by granulocyte colony-stimulating factor after subacute STsegment elevation myocardial infarction undergoing late revascularization: final results from the G-CSF-STEMI (Granulocyte Colony-Stimulating Factor ST-Segment Elevation Myocardial Infarction) trial. J Am Coll Cardiol 2006;48:1712-1721.

45 Ripa RS, Jørgensen E, Wang Y, Thune JJ, Nilsson JC, Søndergaard L, Johnsen HE, Køber L, Grande P, Kastrup J: Stem cell mobilization induced by subcutaneous granulocyte-colony stimulating factor to improve 
cardiac regeneration after acute ST-elevation myocardial infarction: result of the doubleblind, randomized, placebo-controlled stem cells in myocardial infarction (STEMMI) trial. Circulation 2006;113:1983-1992.

-46 Zohlnhöfer D, Ott I, Mehilli J, Schömig K, Michalk F, Ibrahim T, Meisetschläger G, von Wedel J, Bollwein $H$, Seyfarth M, Dirschinger J, Schmitt C, Schwaiger M, Kastrati A, Schömig A: Stem cell mobilization by granulocyte colony-stimulating factor in patients with acute myocardial infarction: a randomized controlled trial. JAMA 2006; 295:1003-1010.

-47 Kang HJ, Kim HS, Zhang SY, Park KW, Cho HJ, Koo BK, Kim YJ, Soo Lee D, Sohn DW, Han KS, Oh BH, Lee MM, Park YB: Effects of intracoronary infusion of peripheral blood stem-cells mobilised with granulocyte-colony stimulating factor on left ventricular systolic function and restenosis after coronary stenting in myocardial infarction: the MAGIC cell randomised clinical trial. Lancet 2004;363:751-756.

-48 Fernández-Avilés F, San Román JA, GarcíaFrade J, Fernández ME, Peñarrubia MJ, de la Fuente L, Gómez-Bueno M, Cantalapiedra A, Fernández J, Gutierrez O, Sánchez PL, Hernández C, Sanz R, García-Sancho J, Sánchez A: Experimental and clinical regenerative capability of human bone marrow cells after myocardial infarction. Circ Res 2004; 95:742-748.

- 49 Schachinger V, Assmus B, Britten MB, Honold J, Lehmann R, Teupe C, Abolmaali ND, Vogl TJ, Hofmann WK, Martin H, Dimmeler S, Zeiher AM: Transplantation of progenitor cells and regeneration enhancement in acute myocardial infarction: final one-year results of the TOPCARE-AMI Trial. J Am Coll Cardiol 2004;44:1690-1699.

- 50 Chen SL, Fang WW, Ye F, Liu YH, Qian J, Shan SJ, Zhang JJ, Chunhua RZ, Liao LM, Lin S, Sun JP: Effect on left ventricular function of intracoronary transplantation of autologous bone marrow mesenchymal stem cell in patients with acute myocardial infarction. Am J Cardiol 2004;94:92-95.

-51 Kang HJ, Kim HS, Koo BK, Kim YJ, Lee D, Sohn DW, Oh BH, Park YB: Intracoronary infusion of the mobilized peripheral blood stem cell by G-CSF is better than mobilization alone by G-CSF for improvement of cardiac function and remodeling: 2-year followup results of the Myocardial Regeneration and Angiogenesis in Myocardial Infarction with G-CSF and Intra-Coronary Stem Cell Infusion (MAGIC Cell) 1 trial. Am Heart J 2007;153:237.e1-237.e8.

- 52 Schachinger V, Erbs S, Elsasser A, Haberbosch W, Hambrecht R, Holschermann $\mathrm{H}$, Yu J, Corti R, Mathey DG, Hamm CW, Suselbeck T, Werner N, Haase J, Neuzner J, Germing A, Mark B, Assmus B, Tonn T, Dimmeler S, Zeiher AM: Improved clinical outcome after intracoronary administration of bone-marrow-derived progenitor cells in acute myocardial infarction: final 1-year results of the REPAIR-AMI trial. Eur Heart J 2006;27:2775-2783.

53 Abdel-Latif A, Bolli R, Tleyjeh IM, Montori VM, Perin EC, Hornung CA, Zuba-Surma EK, Al-Mallah M, Dawn B: Adult bone marrow-derived cells for cardiac repair: A systematic review and meta-analysis. Arch Intern Med 2007;167:989-997.

54 Martin-Rendon E, Brunskill SJ, Hyde CJ Stanworth SJ, Mathur A, Watt SM: Autologous bone marrow stem cells to treat acute myocardial infarction: a systematic review. European Heart Journal 2008 DOI: 10.1093/ eurheartj/ehn220 (ahead of print).

55 Hagege AA, Marolleau JP, Vilquin JT, Alheritiere A, Peyrard S, Duboc D, Abergel E, Messas E, Mousseaux E, Schwartz K, Desnos M, Menasche P: Skeletal myoblast transplantation in ischemic heart failure: long-term follow-up of the first phase I cohort of patients. Circulation 2006;114(suppl 1):I108I113.

56 Menasche P, Alfieri O, Janssens S, McKenna W, Reichenspurner H, Trinquart L, Vilquin JT, Marolleau JP, Seymour B, Larghero J Lake S, Chatellier G, Solomon S, Desnos M, Hagege AA: The Myoblast Autologous Grafting in Ischemic Cardiomyopathy (MAGIC) trial: first randomized placebo-controlled study of myoblast transplantation. Circulation 2008;117:1189-1200.

57 Stamm C, Westphal B, Kleine H-D, Petzsch M, Kittner C, Klinge H, Schümichen C, Nienaber CA, Freund M, Steinhoff G: Autologous bone-marrow stem-cell transplantation for myocardial regeneration. Lancet 2003;361:45-46.

58 Archundia A, Aceves JL, Lopez-Hernandez M, Alvarado M, Rodriguez E, Quiroz GD, Paez A, Rojas FM, Montano LF: Direct cardiac injection of G-CSF mobilized bonemarrow stem-cells improves ventricular function in old myocardial infarction. Life Sci 2005;78:279-283.

59 Chachques JC, Trainini JC, Lago N, Masoli $\mathrm{OH}$, Barisani JL, Cortes-Morichetti M Schussler O, Carpentier A: Myocardial assistance by grafting a new bioartificial upgraded myocardium (MAGNUM Clinical Trial): one year follow-up. Cell Transplant 2007;16: 927-934.

60 Chachques JC, Trainini JC, Lago N, CortesMorichetti M, Schussler O, Carpentier A: Myocardial Assistance by Grafting a New Bioartificial Upgraded Myocardium (MAGNUM Clinical Trial): Clinical feasibility study. Ann Thorac Surg 2008;85:901-908.

61 Backlund EO, Granberg PO, Hamberger B, Knutsson E, Martensson A, Sedvall G, Seiger A, Olson L: Transplantation of adrenal medullary tissue to striatum in parkinsonism. J Neurosurg 1985;62:169-173.

62 Freed CR, Breeze RE, Rosenberg NL, Schneck SA, Wells TH, Barrett JN, Grafton ST, Huang SC, Eidelberg D, Rottenberg DA: Transplantation of human fetal dopamine cells for Parkinson's disease: results at 1 year. Arch Neurol 1990;47:505-512.

63 Freed CR, Greene PE, Breeze RE, et al: Tsai WY, DuMouchel W, Kao R, Dillon S, Winfield H, Culver S, Trojanowski JQ, Eidelberg D, Fahn S: Transplantation of embryonic dopamine neurons for severe Parkinson's disease. N Engl J Med 2001;344:710-719.

64 Hagell P, Cenci MA: Dyskinesias and dopamine cell replacement in Parkinson's disease: a clinical perspective. Brain Res Bull 2005;68:4-15.

65 Kondziolka D, Wechsler L: Stroke repair with cell transplantation: neuronal cells, neuroprogenitor cells, and stem cells. Neurosurg Focus 2008;24:E13.

66 Dezawa M, Kanno H, Hoshino M, Cho H, Matsumoto N, Itokazu Y, Tajima N, Yamada H, Sawada H, Ishikawa H, Mimura T, Kitada M, Suzuki Y, Ide C: Specific induction of neuronal cells from bone marrow stromal cells and application for autologous transplantation. J Clin Invest 2004;113:17011710.

67 Rabinovich SS, Seledtsov VI, Banul NV, Poveshchenko OV, Senyukov VV, Astrakov SV, Samarin DM, Taraban VY: Cell Therapy of Brain Stroke. Bull Exp Bio Med 2005;1: $126-128$

68 Sprigg N, Bath PM, Zhao L, Willmot MR, Gray LJ, Walker MF, Dennis MS, Russell N: Granulocyte-colony-stimulating factor mobilizes bone marrow stem cells in patients with subacute ischemic stroke: the Stem cell Trial of recovery EnhanceMent after Stroke (STEMS) pilot randomized, controlled trial. Stroke 2006;37:2979-2983.

69 Beck H, Voswinckel R, Wagner S, Ziegelhoeffer T, Heil M, Helisch A, Schaper W, Acker T, Hatzopoulos AK, Plate KH: Participation of bone marrow-derived cells in long-term repair processes after experimental stroke. J Cereb Blood Flow Metab 2003; 23:709-717.

70 Lee ST, Chu K, Jung KH, Ko SY, Kim EH, Sinn DI, Seok Y, Lee YS, Lo EH, Kim M, Roh JK: Granulocyte colony-stimulating factor enhances angiogenesis after focal cerebral ischemia. Brain Res 2005;1058:120-128.

-71 Toth ZE, Leker RR, Shahar T, Pastorino S, Szalayova I, Asemenew B, Key S, Parmelee A, Mayer B, Nemeth K, Bratincsak, Mezey E: The combination of granulocyte colonystimulating factor and stem cell factor significantly increases the number of bone marrow-derived endothelial cells in brains of mice following cerebral ischemia. Blood 2008;111:5544-5552.

72 Bang OY, Lee IS, Lee PH, Lee G: Autologous mesenchymal stem cell transplantation in stroke patients. Ann Neurol 2005;57:874882.

73 Leone AM, Galiuto L, Garramone B, Rutella S, Giannico MB, Brugaletta S, Perfetti M, Liuzzo G, Porto I, Burzotta F, Niccoli G, Biasucci LM, Leone G, Rebuzzi AG, Crea F: Usefulness of granulocyte colony-stimulat- 
ing factor in patients with a large anterior wall acute myocardial infarction to prevent left ventricular remodeling (the Rigenera study). Am J Cardiology 2007;100:397-403.

-74 Takano H, Hasegawa H, Kuwabara Y, Nakayama T, Matsuno K, Miyazaki Y, Yamamoto M, Fujimoto Y, Okada H, Okubo S, et al: Feasibility and safety of granulocyte colony-stimulating factor treatment in patients with acute myocardial infarction. Int J Cardiol 2007;122:41-47.

-75 Malafronte C, Achilli F: Stem cells mobilization in acute myocardial infarction (stemAMI trial): preliminary data of a perspective, randomized, single blind trial. Minerva Cardioangiol 2007;55:721-731.

-76 Ellis SG, Penn MS, Bolwell B, Garcia M, Chacko M, Wang T, Brezina KJ, McConnell G, Topol EJ: Granulocyte colony stimulating factor in patients with large acute myocardial infarction: Results of a pilot dose-escalation randomized trial. Am Heart J 2006;152: 1051.e9-1051.e14

-77 Deng Z, Yang C, Deng H, Yang A, Geng T, Chen X, Ma A, Liu Z: Effects of GM-CSF on the stem cells mobilization and plasma C-reactive protein levels in patients with acute myocardial infarction. Int J Cardiol 2006; 113:92-96.

78 Li ZQ, Zhang M, Jing YZ, Zhang WW, Liu Y, Cui LJ, Yuan L, Liu XZ, Yu X, Hu TS: The clinical study of autologous peripheral blood stem cell transplantation by intracoronary infusion in patients with acute myocardial infarction (AMI). Int J Cardiol 2007; 115:5256.

79 Lunde K, Solheim S, Aakhus S, Arnesen H, Moum T, Abdelnoor M, Egeland T, Endresen K, Ilebekk A, Mangschau A, Forfang K: Exercise capacity and quality of life after intracoronary injection of autologous mononuclear bone marrow cells in acute myocardial infarction: results from the Autologous Stem cell Transplantation in Acute Myocardial Infarction (ASTAMI) randomized controlled trial. Am Heart J 2007;154:710.e1710.e8.

-80 Suarez de Lezo J, Herrera C, Pan M, Romero M, Pavlovic D, Segura J, Sanchez J, Ojeda S, Torres A: Regenerative therapy in patients with a revascularized acute anterior myocardial infarction and depressed ventricular function. Rev Esp Cardiol 2007;60:357-365.
81 Tatsumi T, Ashihara E, Yasui T, Matsunaga S, Kido A, Sasada Y, Nishikawa S, Hadase M, Koide M, Nakamura R, Irie H, Ito K, Matsui A, Matsui H, Katamura M, Kusuoka S, Matoba S, Okayama S, Horii M, Uemura S, Shimazaki C, Tsuji H, Saito Y, Matsubara H: Intracoronary transplantation of non-expanded peripheral blood-derived mononuclear cells promotes improvement of cardiac function in patients with acute myocardial infarction. Circ Journal 2007;71:1199-1207.

82 Kang HJ, Lee HY, Na SH, Chang SA, Park KW, Kim HK, Kim SY, Chang HJ, Lee W, Kang WJ, Koo BK, Kim YJ, Lee DS, Sohn DW, Han KS, Oh BH, Park YB, Kim HS: Differential effect of intracoronary infusion of mobilized peripheral blood stem cells by granulocyte colony-stimulating factor on left ventricular function and remodeling in patients with acute myocardial infarction versus old myocardial infarction: the MAG IC cell-3-DES randomized controlled trial Circulation 2006;114(suppl):I145-I151.

83 Yao K, Huang RC, Ge L, Qian JY, Li YL, Xu SK, Zhang F, Zhang YQ, Niu YH, Shi JH, Zhang SH, Fan B, Wang QB, Sun AJ, Zou YZ, Ge JB: Observation on the safety: clinical trail on intracoronary autologous bone marrow mononuclear cells transplantation for acute myocardial infarction. Chinese J Cardiol 2006;34:577-581.

84 Assmus B, Honold J, Schachinger V, Britten MB, Fischer-Rasokat U, Lehmann R, Teupe C, Pistorius K, Martin H, Abolmaali ND, Tonn T, Dimmeler S, Zeiher AM: Transcoronary transplantation of progenitor cells after myocardial infarction. N Engl J Med 2006; 355:1222-1232.

85 Meyer GP, Wollert KC, Lotz J, Steffens J, Lippolt $\mathrm{P}$, Fichtner S, Hecker H, Schaefer A, Arseniev L, Hertenstein B, Ganser A, Drexler $\mathrm{H}$ : Intracoronary bone marrow cell transfer after myocardial infarction: eighteen months' follow-up data from the randomized, controlled BOOST (BOne marrOw transfer to enhance ST-elevation infarct regeneration) trial. Circulation 2006;113: 1287-1294.

86 Janssens S, Dubois C, Bogaert J, Theunissen K, Deroose C, Desmet W, Kalantzi M, Herbots L, Sinnaeve P, Dens J: Autologous bone marrow-derived stem-cell transfer in patients with ST-segment elevation myocardial infarction: double-blind, randomised controlled trial. Lancet 2006;367:113S-121S.
87 Ge J, Li Y, Qian J, Shi J, Wang Q, Niu Y, Fan B, Liu X, Zhang S, Sun A, Zou Y: Efficacy of emergent transcatheter transplantation of stem cells for treatment of acute myocardial infarction (TCT-STAMI). Heart 2006;92: 1764-1767.

-88 Huang RC, Yao K, Zou YZ, Ge L, Qian JY, Yang J, Yang S, Niu YH, Li YL, Zhang YQ, Zhang F, Xu SK, Zhang SH, Sun AJ, Ge JB: Long term follow-up on emergent intracoronary autologous bone marrow mononuclear cell transplantation for acute inferior-wall myocardial infarction. Zhonghua Yi Xue Za Zhi 2006;86:1107-1110.

-89 Karpov RS, Popov SV, Markov VA, Suslova TE, Ryabov VV, Poponina YS, Krylov AL, Sazonova SV: Autologous mononuclear bone marrow cells during reparative regeneratrion after acute myocardial infarction. Bull Exp Biol Med 2005; 140:640-643.

-90 Meluzin J, Mayer J, Groch L, Janousek S, Hornacek I, Hlinomaz O, Kala P, Panovsky R, Prasek J, Kaminek M, Stanicek J, Klabusay M, Koristek Z, Navratil M, Dusek L, Vinklarkova J: Autologous transplantation of mononuclear bone marrow cells in patients with acute myocardial infarction: the effect of the dose of transplanted cells on myocardial function. Am Heart J 2006;152:e9-e15.

-91 Penicka M, Horak J, Kobylka P, Pytlik R, Kozak T, Belohlavek O, Lang O, Skalicka H, Simek S, Palecek T, Linhart A, Aschermann M, Widimsky P: Intracoronary injection of autologous bone marrow-derived mononuclear cells in patients with large anterior acute myocardial infarction: a prematurely terminated randomized study. J Am Coll Cardiol 2007;49:2373-2374

-92 Ruan W, Pan CZ, Huang GQ, Li YL, Ge JB, Shu XH: Assessment of left ventricular segmental function after autologous bone marrow stem cells transplantation in patients with acute myocardial infarction by tissue tracking and strain imaging. Chin Med J 2005;118:1175-1181.

93 Schachinger V, Assmus B, Britten MB, Honold J, Lehmann R, Teupe C, Abolmaali ND, Vogl TJ, Hofmann WK, Martin H, Dimmeler S, Zeiher AM: Transplantation of progenitor cells and regeneration enhancement in acute myocardial infarction: final one-year results of the TOPCARE-AMI Trial. J Am Coll Cardiol 2004;44:1690-1699. 